Status Report 2016-2019

\title{
Climate Change Variability Through Lacustrine Records Published During 2016-2019: Implications, New Approaches, and Future Direction
}

\author{
BINITA PHARTIYAL*, ANJUM FAROOQUI and TRINA BOSE \\ Birbal Sahni Institute of Palaeosciences, 53, University Road, Lucknow 226 007, UP, India
}

(Received on 25 August 2019; Accepted on 28 September 2019)

\begin{abstract}
During the last four years, upcoming innovative technologies are fast developing to produce high-quality, high resolution, non-destructive down- core analyses. These lead to physical and chemical characterisations of sediments and environmentally significant biotic proxies at decadal to sub-annual timescales. This paper reviews the application of biotic and abiotic proxy analysis to integrate and infer recently procured lacustrine records from the Indian subcontinent. The problems in chronology, quantification, and interpretation are discussed, leading to possible precautions or solutions for future paleoclimate research. In the Subcontinent, signs of anthropogenic climate change are increasingly visible, especially in enclosed lake basins. Significant among these signs are: shrinking and eutrophication of low altitude tropical lakes; expansion of glacial lakes; increasing primary productivity in high latitude/altitude lakes; frequent landscape changes, coastal erosion, saline water intrusion in coastal lakes, industrial pollution near cities.
\end{abstract}

Keywords: Lacustrine; Quaternary; Holocene; Proxy-data; Palaeoclimate; Eutrophication

\section{Introduction}

The Indian subcontinent is unique in its setting, geology, populace, and interactions between all its spheres. The historically high population density in this region leads to long-term feedback between industrial activities and climate. Preserving a few of the oldest human-climate interaction records (Petrie et al., 2017), this is a perfect observatory to study long and shortterm earth interactions and their input to climate change.

Lacustrine records constitute an important archive for the reconstruction of palaeoclimate in a terrestrial setting. The limited basin size of lakes makes them exceptional concentrators of chemicals input from surroundings, a hub of high concentration chemical reactions, and hence emits large amounts of various types of gases. Due to this, climate proxies from lakes store heightened amplitudes of atmospheric and hydrological parametrial changes in their source regions (Dee et al., 2018).

One of the primary problems in climate change studies is the assessment of long-term processes in

\footnotetext{
*Authorfor Correspondence: E-mail: binita_phartiyal@bsip.res.in
}

natural and anthropogenic combinations. Highresolution lake studies are one of the principal methods to gain this information for the recent past (Smerdon et al., 2015; Butcher et al., 2015). India has numerous lakes covering all ranges in size, climate zones, formation types, and other characteristics. This region has lakes completely untouched by humanity as well as lakes, which are engulfed by urbanisation (Jain et al., 2007). Further, we have many palaeolake sequences available to study pre-industrial and prehuman conditions (Kumar et al., 2017).

Across the Indian subcontinent, recent abundance in advanced instruments has enabled scientists to generate high resolution qualitative and quantitative datasets from the Quaternary lake deposits in India. This improvement leads to depositional history and environmental change information in higher resolution than ever before. More than 40 papers published in the peer-reviewed journals since 2016 on Indian lakes signifies this evolution.

A review on the lacustrine palaeoclimate records 


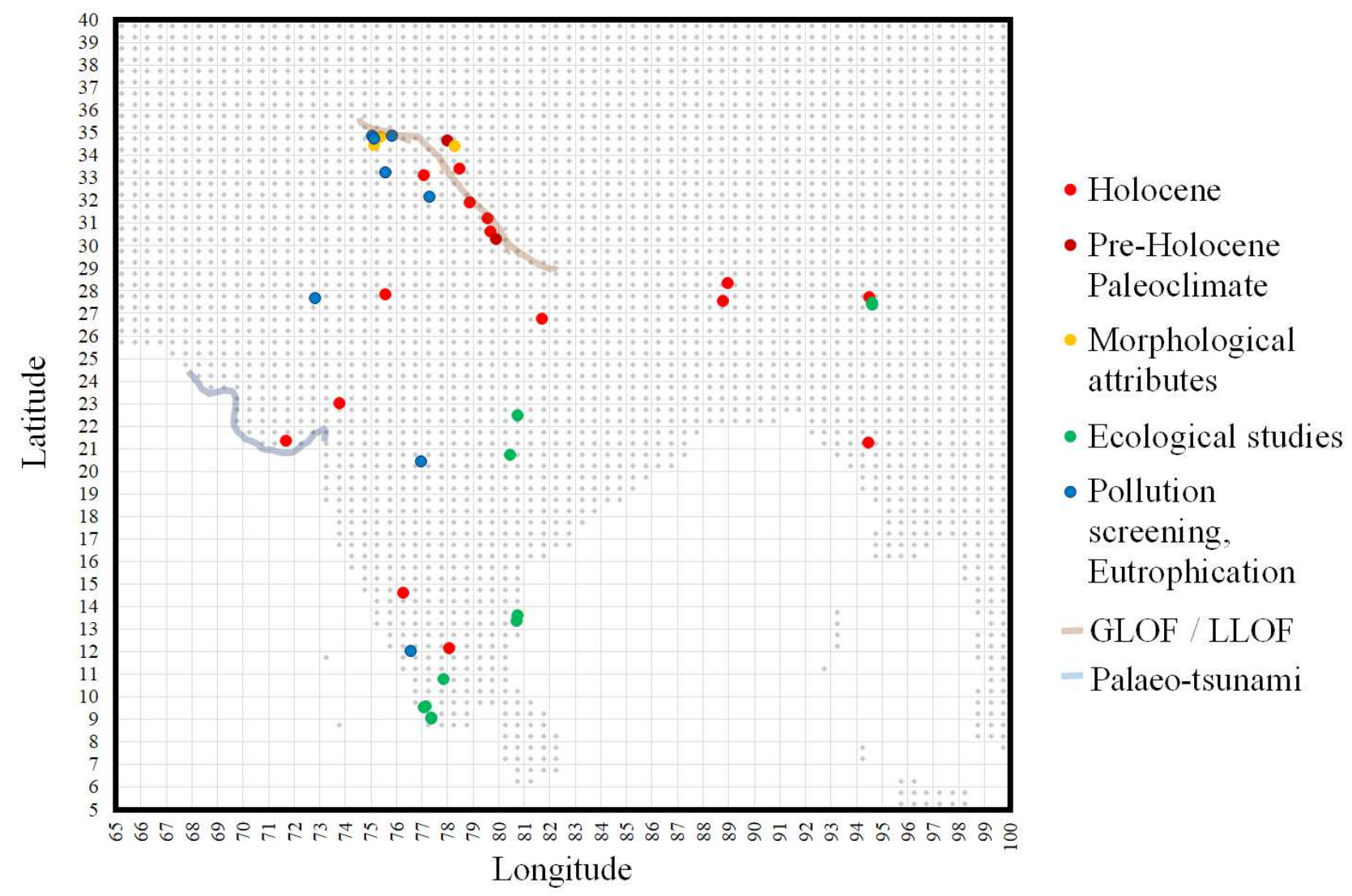

Fig. 1: Locations of the lacustrine records published during 2016-2019

with a wide range of proxy datasets classified in terms of geographical regions is offered here to depict current and future trends in Quaternary studies. All the time periods are given in calibrated years Before Present. These published datasets varied from downtime climatic records to ecological conditions and monitoring of the present-day lakes, wetlands and backwater areas. The data of the climatic variations are in higher number for the Holocene and is majorly from the northern part of India, while the southern lakes represent more ecological and morphological research. There are a few records of palaeo-tsunami in the west coast along with glacial and landslide lake outburst flood (GLOF, LLOF) monitoring from the Himalayan and Karakorum ranges.

\section{The Mountainous Lakes of Himalaya}

In the geodynamically active Himalaya, the palaeofluvio-lacustrine facies records, as well as currently existing small and big lakes are found in great numbers. Horizontal compression of the lithosphere, topographic uplift, erosion, and sedimentation are characteristics of the Himalayan topography ever since this collision, makes the entire area tectonically active even till today (Valdiya, 1988, 2001). The Indian Himalayan Range has 16,627 glaciers which cover an area of 40,563 sq. km. Changes in glacier discharge are also climate-induced and may significantly impact the glacial and valley lakes. Due to the combination of tectonic instability and climatic variation, damming of river valleys at narrow constricted places and formation of tectonic lakes is a common phenomenon in the Himalayan mountains (Phartiyal et al., 2005; Pant et al., 2005; Phartiyal et al., 2009; Phartiyal and Sharma, 2009). These lake records are good palaeoclimate archives because of continuous sedimentation during their existence. In the last three years, a good set of data from the Himalayan lakes has been published.

Mujtaba et al. (2018) and Lal et al. (2019) report that, during the late Quaternary, the Indus River was dammed at least twice. The resulting lakes existed between $125 \pm 11,87 \pm 8$ kyrs during marine isotopic stage (MIS) 5 and 72-49 kyrs through cold-stage MIS4. 
In continuation of their previous work in Tso Moriri Lake, Ladakh (Mishra et al., 2014, 2015a,b), Prasad et al. (2016) showed that the documentation of catchment end members is essential for the application of the conventional indicators of LPP (C/ $\mathrm{N}$ and isotopic co-variance) in high altitude oligotrophic lakes with high erosion rates. In the Tso Moriri Lake, the application of productivity indicators is limited by the low $\mathrm{C} / \mathrm{N}$ in catchment and high erosion rates which mask the LPP signal. Additionally, (i) the isotopic composition of bulk organic matter is controlled by both the source $\left(\delta^{15} \mathrm{~N}_{\text {org }}\right)$ and salinity $\left(\delta^{13} \mathrm{C}_{\text {org }}\right)$; (ii) the $\delta^{13} \mathrm{C}$ of planktons is strongly influenced by the isotopic enrichment of lake waters once a salinity threshold is crossed (marked by the appearance of endogenic aragonite in Tso Moriri Lake).

The same group extended their work in this lake (Mishra et al., 2018a) to identify two steep lake level rises of $65 \mathrm{~m}$ (16.4-12.6 kyrs) and $47 \mathrm{~m}$ (11.2-8.5 kyrs) respectively linked to stronger snow-melt and higher annual precipitation. In contrast to the onset of ISM (BoB branch) at ca. $14.7 \mathrm{kyrs}$ in lower altitudes in NE India, the hydrological signature of ISM in highaltitude Himalaya is seen only between 12.7 and 12 kyrs indicating a later onset of ISM precipitation. The strength of the Siberian High limits the eastward penetration of the westerlies until 8 kyrs, following which the onset of the wet phase is seen in central Asian lakes and in NW India.

Dar et al. (2015) studied the morphological (both micro and macro-morphological) attributes of loesspalaeosols in the Karewa palaeolake of Kashmir Valley, India, suggest a variation in climatic conditions during the Late Quaternary period.

Ranhotra et al. (2018) reconstructed palaeoclimatic variations from $\sim 16.6-3.5 \mathrm{kyrs}$ based on the palynological and magnetic susceptibility proxies Rukti, Sangla Valley, Kinnaur. The climate was warm and moist during $\sim 16.6 \mathrm{kyrs}$ and changed to cool $\sim 13.3$ kyrs, followed by increasing ISM since $\sim 11.5$ kyrs. A distinct spike in the magnetic susceptibility values between $\sim 8.7$ and $\sim 7.8$ kyrs correspond to global 8.2 kyrs cool event. Subsequent warm conditions could be generalised by the advancement of broad-leaved Birch (Betula) line to higher altitude following the resultant retreat of the glacial body.

Pollen data from Triloknath palaeolake (Bali et al., 2017) revealed the changing vegetation pattern and climatic conditions in the Lahaul region since the Mid-Holocene. Around 6300 to 5379 yrs, the region supported broadleaf forest (BLF) indicating a warm and moderately humid climate. Between $\sim 5379$ and 3167 yrs, BLF declined, and coniferous forests expanded, reflecting weakened SW monsoon. The coniferous forests proliferated around 3167 to 2228 yrs, indicating further weakened monsoon. Around 962 to 300 yrs, monsoon strengthening was seen in increasing BLF and a contemporary reduction of coniferous forests. During the last 300 yrs (1650 AD onwards) cool climatic phase was recorded in the sharp decline of broad-leaved forests.

Srivastava et al. (2017) have reconstructed a $\sim 50$ years temporal resolution, 8000-year monsoonal record from Kedarnath, revealing reinforcement of tropical and global climate systems since midHolocene. This record provides compelling evidence for a reorganisation of the global climate system taking place at $\sim 5.5$ kyrs possibly after sea level stabilisation and the advent of inter-annual climate variability governed by the modern ENSO phenomenon. The ISM record also captures warm-wet and cold-dry conditions during the Medieval Climate Anomaly and Little Ice Age, respectively.

Bhushan et al. (2018) observed from the Benital lake, Pinder valley that the periods of drift-ice events inferred based on the increase in the Hematite Stain Grains (HSG) correlates reasonably well with the low concentration of detrital proxies implying reduced precipitation induced run-off in the lake catchment (weak ISM).The present study thus indicates that the short-term ISM variability in the central Himalaya was coupled with the northern latitude climatic events and solar forcing played a major role in modulating the Holocene millennial to centennial-scale climatic fluctuations. The six phases of enhanced ISM with variability are dated between 10,000-9600, 9500-9200, $8600-5800,5000-4200,3500-2400$ and $1800-1000 \mathrm{yrs}$.

The landslide dammed palaeolake at Dwarahat in Kumaun (Sanwal et al., 2019) shows a warm and moist climate with intensified monsoon with high vegetation growth of $\mathrm{C}_{3}$ type at $\sim 26 \mathrm{kyrs}$. This phase gradually gives way to prolonged cold spell with an abundance of $\mathrm{C}_{4}$ plants. This interval of aridity corresponding with the LGM gradually transits into a 
warm and moist climate or intense summer monsoon at $\sim 15$ kyrs. This phase is followed by depleted precipitation and dominance of $\mathrm{C}_{4}$ vegetation, marking the Older Dryas (14-13 kyrs). A prominent warm spike at the top end of the profile probably corresponds with the Allerød oscillation, around 12 kyrs.

The most complex and devastating interactions between climate and hydro-morphological processes in mountain environments, Landslide Lake Outburst Floods (LLOF's) and Glacier Lake Outburst Floods (GLOF's) are studied extensively by S.K. Allen and group (Linsbauer et al., 2016; Allen et al., 2016a,b,c,d; Ruiz-Villanueva et al., 2017; Allen et al., 2018). They assess landslide risks in Himalaya and Karakoram ranges via field and satellite observations, modelling studies etc. of permafrost, slope angles, snow cover depletion, elevated streamflow, rapidly expanding lakes and associated hydrometeorological variables.

Shah et al. (2017), Babeesh et al. (2017), and Lone et al. $(2017,2018 \mathrm{a}, \mathrm{b})$ studied spatial distribution of grain size, geochemical analysis, $\mathrm{C} / \mathrm{N}$ ratio, calcium carbonate, organic matter etc. of the lake bottom sediments of Wular, Manasbal, and Anchar Lakes in Kashmir valley. They suggest that continued monitoring and restoration efforts are necessary to preserve the pristine lake ecology. The agricultural pollution in Wular lake induces high phytoplankton growth and diatoms indicating high organic pollution reacting with the alkaline environment. Manasbal shows low to moderate pollution except for few stations towards the southern and south-eastern side of the lake. The agricultural and urban sites on the freshwater Anchar lake show higher contamination in sediment. An assessment of sediment contamination results revealed potential risks ranging from moderate to strong for the lake environment, particularly towards areas proximal to agricultural and land-use sites.

The data from Rewalsar Lake, Himachal Pradesh (Sarkar et al., 2016; Meena et al., 2017) for last 50 years using ${ }^{137} \mathrm{Cs}$ and metal screening with ${ }^{210} \mathrm{~Pb}$ chronology shows that the Himalayan lakes are degrading due to increase in toxic heavy metal loading. Before 1990 CE, metal loading was dominated by the lithogenic input and is controlled by the anthropogenic factors afterwards. The higher concentration of $\mathrm{Pb}$ seems to be derived from fossil fuel burning, while the $\mathrm{Cr}$ concentration points to increasing use of fertiliser in the catchment area.
Modelling of high-resolution carbon isotope signature $\left(\delta^{13} \mathrm{C}\right)$ of sediment organic matter (SOM), total organic carbon (TOC), sediment texture and environmental magnetic data from Chopta valley, Sikkim (Ali et al., 2018) shows that the early phase of the Holocene witnessed dramatic centennial to millennial-scale abrupt precipitation fluctuations. Their study suggests that the precipitation was marginally low as compared to present and punctuated by centennial-scale dry spells. Further, the area seems to have been under the influence of enhanced midlatitude westerlies during dry spells like YD and LIA.

Ghosh et al. (2018) report from multi-proxy data of a dried lake near Darjeeling that for the two most significant northern hemispheric RCCs, i.e. MWP and LIA, wet conditions are observed in the eastern Himalaya. However, LIA and post- LIA phases show considerable contrasting trends between peninsular India and eastern Himalaya as well as northeast India, which may be due to the variations in the frequency distribution of active-break periods.

Pollen data from the Loktak Lake in Manipur (Tripathi et al., 2018) shows that there was a warm and relatively dry climate between 2330 and 1460 yrs, followed by two pollen subzones of relatively humid during 1460 and 1150 yrs and more humid climate between 1150 to 560 yrs.

\section{The Lakes of Indus-Saraswati-Ganga- Brahmaputra Plains}

In this section, we include all published lake records from Gujarat to Assam covering all major river plains of India. The western side, termed the IndusSaraswati Plains, includes the Rann of Kachchh and the Thar Desert, consisting of an undulating plain with an average elevation of about $325 \mathrm{~m}$ AMSL. Several saline lakes in this area source economically important salts such as the common salt. Sambhar, Didwana, Degana, Kuchaman, etc. are some of the important lakes.

The Punjab Plain is formed by five main tributaries of Indus with a total area of about 1.75 lakh sq. $\mathrm{km}$ and an elevation of $250 \mathrm{~m}$ AMSL. The area between the Ghaggar and the Yamuna rivers acts as water-divide between the Indus and Ganga watersheds. Ghaggar is the only large river between the Yamuna and the Satluj which is not a tributary to 
either and is considered to be the present-day successor of the legendary Saraswati river.

Ganga Plains is the largest unit of the Himalayan foreland basin with $\sim 375$ thousand sq. $\mathrm{km}$ area. The Ganga along with its large number of tributaries originating in the Himalaya bring large quantities of alluvium from the mountains and have been depositing in this region since Pleistocene to build this extensive plain. Large peninsular rivers such as Chambal, Betwa, Ken, Son, etc. also join Ganga contributing to the formation of this plain. The general slope of the entire plain is to the east and south-east, and the area is marked by local prominences such as levees, bluffs, oxbow lakes, marshes, ravines, etc.

The Brahmaputra valley is an aggradational plain built up by depositional work of the Brahmaputra and its tributaries. The innumerable tributaries of braided Brahmaputra river form several alluvial fans. This plain is known for its river islands and wetlands with temporary interactions with the main river via flooding.

The Ganga-Brahmaputra Delta is the largest in the world. Two-thirds of the area is below $30 \mathrm{~m}$ above mean sea level. The seaward face of the delta is studded with a large number of estuaries, mudflats, wetlands, mangrove swamps, sandbanks, islands and forelands and a large part of the coastal delta is covered by tidal forests-the Sunderbans.

Gill et al. (2017) have assessed the mean annual precipitation needed to sustain the Lake Sambhar in Rajasthan during the mid-Holocene with a simple lake model based on the hydrological principals. The calculations revealed that during early Holocene rainfall (average) was $40-50 \%$ greater than present levels and the lake was filled to its maximum $(21 \mathrm{~m}$ above present level) during mid-Holocene. Despite overall climatic stability of the Holocene, the monsoons in India, both summer, and winter show various episodes of weakening and strengthening during this time interval.

Van Oldenborgh (2018) attributed the extreme atmospheric temperature on 19th May 2016 in Phalodi, Rajasthan to increase in aerosols from air pollution and evaporation enhanced by irrigation resulted in greenhouse gas concentrations.

Raj et al. (2015) studied a sediment core from
Pariyaj Lake, in the Vatrak River basin, located at the desert margin. Their results represent a very humid climate and high precipitation/discharge leading to lakehigh-stand around 11 kyrs followed by shrinkage of the lake $\sim 8000$ to $9000 \mathrm{yrs}$ indicating a very dry spell. Another dry event between 5864 and 4680 yrs documented in Pariyaj Lake record is synchronous with various proxy records of the mid-late Holocene Afro-Asiatic monsoonal belt. The period between $\sim 4680$ to 3500 yrs shows a good density and diversity of flora. The contribution of winter precipitation at 7630 yrs and after $\sim 4680$ yrs can be correlated with similar records from other lakes of the region.

From Kikar Tal, Raebareli in Ganga plains, Saxena and Trivedi (2017) report that this area had forest groves since $8000 \mathrm{yrs}$, which diversified and become dense in composition after 7200 yrs. From $4200 \mathrm{yrs}$, a decrease in their frequency was observed, suggesting a warm and moderately humid climate with a reduced monsoon. After 1800 yrs, present open grassland vegetation corresponding to reduced monsoon precipitation is visible, with the shrinkage of lake area.

Multi-proxy records from Nikahari Tal (Saxena and Singh, 2017), a cut-off meander in the Chhoti Gandak basin indicate wet and dry events in the Indian summer monsoon since $1350 \mathrm{CE}$ to Present. Deposition of clay and paucity of arboreal flora suggests weak Indian Summer Monsoon (ISM) around $1350 \mathrm{CE}$. Significant increase in tree and shrubs along with the increase in marshy and aquatic elements indicates enhanced precipitation from $\sim 1420$ to 1620 CE. During 1620 to $1700 \mathrm{CE}$, the arboreal and terrestrial herbs became less diversified along with exceptionally high percentages of clay elucidating weak ISM during the Little Ice Age. From $1850 \mathrm{CE}$ onwards, the trends of arboreal and aquatic taxa along with relatively increased silt content suggests a moderately warm and humid climate.

In Lashoda Tal in Gomti and Sai rivers interfluve region, Trivedi et al. (2019) see geomorphic features such as active streams, abandoned channel belts, stagnant water bodies and alluvial ridges etc. They report the formation of new incipient drainages with low drainage density and seasonally formed small ponds and puddles due to NEM (North-east monsoon) and weakened SWM (South-west monsoon) during 24,212-22,200 years. 
The active mudflats of Rohisa, southern Saurashtra (Banerji et al., 2019) showed the signatures of Roman Warm Period (RWP: 2500-1450 yr. BP), Medieval Warm Period (MWP: 1050-650 yr. BP), Little Ice Age (LIA: 650-100 yr. BP), etc. which were earlier assumed to be a local climatic episode observed in European countries. The weathering intensity and in-situ productivity in the region indicate improved ISM during RWP and MWP. The southward migration of ITCZ enhanced the prevalence of ENSO events accompanied by NAO- phase led to improved winter precipitation during LIA in the region. This study also highlights the crucial role played by the lower latitude volcanic aerosol in influencing the migration of ITCZ, thereby affecting the local as well as the global climate.

Ghosh et al. (2019b) studied a section from Kalpi in Middle Ganga Plains to report three sedimentary packages (Lithofacies associations) as a floodplain, channel and interfluve deposits. The floodplain facies association was deposited by cratonic high sinuosity channels $\sim 114$ ka probably related to MIS-5e and MIS-5d, a time period of high moisture that supported soil formation and was relatively tectonically stable. After a major hiatus about $\sim 30 \mathrm{ka}$, the second sedimentary package comprising conglomerates of channel origin prograded as coalescing fans at 80-54 ka due to forebulge tectonics which is evidenced by increased sediment supply and an extensional regime in the distal part of the foreland. This gravelly channel facies indicates its deposition by low sinuosity meandering channels during MIS-5a and MIS-4, representing a warm and humid climate. The last phase was initiated at $\sim 54$ ka with laterally extensive fine silty clay to clayey silt intervening with sand lenses deposited by small meandering channels and commencement of ravine formation.

Palynological data of the Sakali and Duboi wetlands in the Majuli River Island, a part of the IndoBurma hotspot (Basumatary et al., 2018b) shows that flooding patterns of these two wetlands differ due to their contrasting proximities to the main rivers in this area. i.e. Brahmaputra and Subansiri. Sakali wetland being flood-prone shows high diversity and richness in the palynoassemblages reflecting frequent fluvial activity in the wetland. On the other hand, Duboi wetland is dominated by local arboreal taxa and low abundance or complete absence of extra-local 'flood indicator' taxa.

\section{Varied Lakes of Peninsular India}

The lakes in Peninsular India are as varied as geological periods of its bedrock. These lakes have been studied in diverse ways to inform us about topics such as extremophile biology, anthropogenic pollution and paleo-monsoon etc.

In Lonar impact crater lake, Sivaram et al. (2018) observe a high/low-velocity contrast within 10$15 \mathrm{~m}$ depths corresponding to the highly pressurised and fractured ejecta layer, followed by another layer overlying deeper bedrock basement with depths varying between 200 and $600 \mathrm{~m}$. A low-velocity layer of $\sim 1500 \mathrm{~m} / \mathrm{s}$ extends about $600 \mathrm{~m}$ below the ejecta region. Ray et al. (2017) report with petrographic studies and geochemistry palaeosols confirm no effect of pre-impact weathering on the composition of the Lonarimpactites. Detailed gene sequencing (Paul et al., 2016) revealed a diverse and distinct landscape of bacterial fauna in sediments and water samples of Lonar, carrying out central biogeochemical functions such as methylotrophy, sulphate reduction, etc. Sharma et al. (2016) have reported a novel alkaliphilic actinomycete strain, was isolated from a soil sample collected from the vicinity of Lonar Lake.

Humane et al. (2018) studied the Gadchiroli Lake, Maharashtra and for the physicochemical parameters, geochemistry and sedimentary diatom assemblages. The overall hydro-chemical analysis suggests that the lake water is deteriorated due to the increased anthropogenic activities. The higher concentration of $\mathrm{SiO}_{2}, \mathrm{Al}_{2} \mathrm{O}_{3}$ and $\mathrm{Fe}_{2} \mathrm{O}_{3}$ may be mainly due to the enhanced weathering of these rocks and soil in the watershed for the Gadchiroli Lake. The dominance of the centric diatoms such as Aulacoseiragranulata and Cyclotellameneghiniana indicates that water from the Gadchiroli Lake was more eutrophic with increased productivity and high conductivity.

Sandeep et al. (2017) present an 11,000-year palaeomonsoon record from Shantisagara Lake. The $11,100-10,700$ yrs had a weak ISM; 10,700 to 8600 yrs was characterised by intensified ISM, corresponding to the Early Holocene Optimum; 8600 to $4500 \mathrm{yrs}$ with a weakened ISM; 4500 to $3300 \mathrm{yrs}$ characterised by fluctuating monsoonal conditions and 3300 yrs to the Present with a slight increasing trend in ISM. A similar pattern is also documented in many 
palaeomonsoon records from the region.

Basu et al. (2017) in their study using lipid biomarkers (n-alkanes) distribution and carbon isotopic composition of organic matter $\left(\delta^{13} \mathrm{C}_{\mathrm{O}} \mathrm{M}\right)$ on sediments (catchment, surface and core) and modern vegetation samples in and around lake Ennamangalam, South India give a comprehensive study on with focus on the reconstruction of past climate since past $4800 \mathrm{yrs}$ and observe increased precipitation in the region $\sim 3$ kyrs ago.

Early-Holocene to present palaeo environmental shifts and short climate events from the tropical wetland and lake sediments, Kukkal Lake (Vijayaraj and Achyuthan, 2016) and Nilgiri Hills, Southern India (Raja et al., 2018, 2019) has been studied through multi-proxy biotic and abiotic records indicating palaeo environmental shifts and short climatic events of monsoonal fluctuations.

Palynological investigations from Kathali wetland in Garo Hills (Basumatary et al., 2018a) show the presence of a warm and humid climate between 4620 and $1030 \mathrm{yrs}$, indicating a consolidation of tropical mixed deciduous forest. Grasses and other cultural taxa decreased at this phase, indicating poor pastoral activities at this time interval. The region experienced a less warm and humid climate since $560 \mathrm{yrs}$ as a consequence of reduction in monsoon precipitation and a rise in pastoral activities (human settlement) with the first appearance of cereals.

\section{Coastal Lakes}

A discrepancy between marine and terrestrial biotic indicators is observed due to hydrographic variations in different parts of the coastal areas in the Indian peninsula. A delayed response of different proxies with dynamic changes in coastal ecology is recorded chronologically. Results reveal that the vertical stack of Holocene sediments may have been deposited in the past at varying degree of dynamics and magnitudes of sea-level rise and fall. Here, the chronological similarity of events is uniform all along the Indian coastline, which has been primarily induced by climate change, which defined the sedimentation and coastal geomorphology. The sedimentary sequence through various proxy records provide a high-resolution data of regional Quaternary/Holocene climate warming with an increase in aridity during the last 3 millennia.
This is attributed to a steady increase in atmospheric temperature which is witnessed globally and has induced ecological changes in oceans and terrestrial water bodies in the Indian-subcontinent too.

At present, the modern coastal or deltaic plain of the east coast of India is prone to land subsidence and erosion (Farooqui et al., 2016). Given this, the previous records of sea level during middle Holocene are estimated $+5 \mathrm{~m}$ around $6 \mathrm{ka}$ and $+3 \mathrm{~m}$ around 7.3 $\mathrm{ka},+4 \mathrm{~m}$ in Sulurpet around $6 \mathrm{ka}$ in Andhra Pradesh and $-2 \mathrm{~m}$ around $5.6 \mathrm{ka}$ in Annamalainagar (west of Pichavaram estuary) in Tamil Nadu. In other words, the record of intertidal/estuarine deposition on land that took place $\sim 5-7 \mathrm{ka}$ is now present at different depths suggesting uplift/subsidence in the vertical stack of sediment deposited during Holocene. However, some sectors along the coastal areas are in the process of sediment accretion. Sporadic studies from the east coast of India are inadequate to infer sea-level changes during the Quaternary period. Therefore, more data is required to understand the Holocene sea-level changes and the sectors of subsidence along the east coast of India to highlight the vulnerable areas that may be severely get affected by the predicted climate change.

Kathiresan (2018) reviewed the aesthetic, medicinal and economic values of coastal vegetation, mangroves, in particular, stressing on the importance of understanding the ecological conditions, sedimentation and coastal geomorphological changes influencing hydrodynamics. Such frequent changes become barriers to natural regeneration and afforestation plans. The records of vegetation shifting or replacement in response to climate-induced sealevel changes get buried in the sedimentary sequences and are likely to provide chronological events that occurred in the past.

Ghosh et al. (2019a) developed a Digital Elevation Model (DEM) data to assess the impact of inundation due to the mean sea level rise in Sunderbans, West Bengal. These geospatial techniques reveal that a larger estuarine area is under subsidence by $-2.4 \mathrm{~mm} / \mathrm{yr}$ relative to the baseline year since 2000. A massive change in coastal flora and fauna is expected. Payo et al. (2016) also reported the destruction of mangroves from this area.

The chronology of the relative sea-level fall and 
rise is also recorded from the south-eastern coast of India through palynological results (Srivastava and Farooqui, 2017a,b; Srivastava et al., 2018). Here the multi-proxy data indicates an abrupt climatic fluctuation in a short span of time affecting mangrove vegetation diversity induced by frequent ecological changes.

An extreme event of heavy rainfall was studied through biotic and abiotic proxies in sediments deposited after abrupt flooding in 2015 (Santhanam et al., 2018) that occurred in Chennai and adjoining south-east areas causing great human and economic loss. Unique records of brackish water diatom bloom (Biddulphiabid dulphiana) were observed which served as good indicators of such extreme flooding events affecting the coastal wetlands. Such studies which illustrate the amalgamated dataset of biotic and abiotic proxies during extreme events in the present environment is in high demand as a modern analogue to be used for the study of past events, its cyclicity and future predictions.

Prizomwala et al. (2018) for the first-time report geological evidence of the $1008 \mathrm{CE}$ tsunami, also mentioned as 'an enigma' in the historical reports, by identifying a $>250 \mathrm{~km}$ long sand sheet with a landward extent of more than $250 \mathrm{~m}$ from the Indian coastline with detailed sedimentology and geochemistry proxy studies. The 2004 Sumatra-Andaman tsunami emphasised the catastrophic nature of such disasters and exposed the knowledge gap of the historical and palaeo events. The northern Arabian Sea, which hosts a similar tsunamigenic source, i.e. the Makran Subduction Zone (MSZ), has so far remained 'TerraIncognita'. Here, the report of the AD 1008 event from the Indian coastline, also supports the claim that the Western MSZ, albeit at longer intervals, has experienced major thrust earthquakes $\left(\mathrm{M}_{\mathrm{w}}>8\right)$ in the historical past. The proximity of this sand sheet to the shoreline does not discount the role of extremely unlikely, large storms as its causal mechanism.

Sajinkumar et al. (2017) in his paper from the backwater of Veli-Akkulam, adjoining the Arabian Sea in the south-west part of Indian Peninsula, showcases how an urban agglomeration alters wetland system located within a tropical monsoonal environment. A spatiotemporal analysis has shown that the lake and adjacent wetlands are shrinking at a fast pace and the lake is under threat to eutrophication.
Over about seven decades, the lake has shrunk by $28.05 \%$ and the wetlands by $37.81 \%$.

Sreekumari et al. (2016) studied the Sasthamkotta lake in the southwestern coast serving as a drinking water source for about seven lakh people in southern Kerala. Unfortunately, the lake is at the verge of severe degradation consequent to different kinds of human interferences. The authors discuss in detail the pros and cons of the human-induced environmental degradation of the Lake Sasthamkotta, declared Ramsar wetland of international importance recently. Based on the study, a set of recommendations are also drawn for improving the overall environmental quality of the Sasthamkotta lake in particular and the freshwater lakes in the coastal lands of densely populated tropics in general.

Basavaiah et al. (2018) compared the results of pre-tsunami sediments from onshore and offshore with our post-tsunami sand dominated sediments from Muttukadu backwater. They found enrichment and dilution of specific elements ( $\mathrm{Fe}, \mathrm{Mn}, \mathrm{Pb}$ ), which are found in the offshore regions. The study also generated a database of mineral magnetic properties of 2004 Indian Ocean Tsunami deposits from Chennai coast. They concluded that in combination with textural and geochemical analyses, mineral magnetic technique can serve as a proxy for the tsunami-induced deposits.

Pollution caused by industrial and urban activities around the city of Chennai has been studied in detail by Veerasingam et al. (2016); Mugilarasan et al. (2017); Manikandan et al. (2018).

\section{Integrated Studies}

The bulk organic matter $\delta^{18} \mathrm{O}$ anomalies from Sahiya Cave in northern India and central Indian Lonar Lake (Mishra et al., 2018b) indicate opposing climate trends which are most significant between 810-1300 AD. They propose that either an increase in westerly precipitation in northern India or enhanced contribution from the BoB branch of the ISM to northern India could have resulted in this observed N-S hydrological differences.

Misra et al. (2018), did a review of the seventysix Holocene lake records from India, dividing them into eight classes according to the diverse geomorphic and climatic zones of our country. This also helps in understanding regional-scale variations in terms of both 
qualitative and quantitative assessment of the available proxy data. According to the authors, multiple lake proxies indicate fluctuating lake levels throughout the Holocene and also show regional scale coherence for specific climatic events. A peak in monsoon strength between 9 and 5 kyrs BP is recorded, which corresponds to the globally recorded Holocene Climate Optima. Later a general trend in aridity is recorded throughout India after 4 kyrs BP.

Kar and Quamar (2019) have done a review of the Quaternary palaeoclimatic studies in India, concerning palynology, where the recent progress of palynology in India, regarding Quaternary palaeoclimatic studies, was discussed and reviewed.

Menzel et al. (2015) studied four lakes in different parts of India; the oligotrophic, closed alpine Tso Moriri in Ladakh; the subtropical tectonic Mansar lake in Lesser Himalaya, the anoxic, eutrophic crater lake Lonar in central India's core monsoon zone and the oxic, meso- to eutrophic Pookode lake in southern India for comprehensive amino acid (AA) analyses. Results indicate that differences in organic matter sources and the environmental properties of the individual lakes are responsible for major variability in monomeric AA distribution; however, the PCA also gives a factor that most probably separates the samples according to their state of organic matter degradation. Using the factor loadings of the individual AA monomers, a lake sediment degradation index (LI) that might apply to other palaeo-lake investigations has also been suggested by the authors.

\section{Future Directions}

For lacustrine records from the subcontinent, we identify the following points to be pursued in the upcoming research.

\section{Chronology: Advantages and Limitations}

Chronology of geological events has immense significance and becomes even more important for the Quaternary Period because during this the earth has gone through glacial and interglacial phases alternatively. In high-resolution lake data, anaccurate chronology is an essential component of the interpretation.

Conventional and AMS ${ }^{14} \mathrm{C}$ radiometric dating is the most widely used technique in lake studies. These methods have limitations like the requirement of measurable organic carbon content in sediment and relatively precise age till up to 50,000 years only. Further, in limestone terrains records, conventional ${ }^{14} \mathrm{C}$ radiometric dates face problems due to reservoir effect.

In the same palaeolake sequence, the ${ }^{14} \mathrm{C}$ AMS dates are much younger (Phartiyal et al., 2013) than conventional ${ }^{14} \mathrm{C}$ dating techniques (Phartiyal et al., 2005). The same sequence studied by optically stimulated luminescence technique (Sangode et al., 2013; Blöthe et al., 2014; Lal et al., 2019) leads to even older but relatively comparable chronology to ${ }^{14} \mathrm{C}$ conventional ages in Phartiyal et al. (2005).

To solve this chronology technique-based limitation, it is essential that more emphasis must be given to understand the geological features and processes to ascertain the relative stratigraphy of a region. Afterwards, a combination of different dating techniques is to be applied for establishing the chronology before proposing the palaeoclimatic record of a particular region.

\section{Proxy Response}

In Quaternary palaeoclimate, it is a common practice that authors try to include several climate proxy parameters of a single site. But they are usually interpreted on same timescale. Further, it is well studied that different proxies do not react to climate on same timescale (Blaauw, 2012; Khider et al., 2017; Liu et al., 2018). Indian region still lacks research which throws light on how the different proxies respond in space and time to the climatic changes that are taking place. This is an important direction we should work in for a reliable, processbased and accurate understanding of past climate.

\section{Monsoons - A Dynamic Component}

There are three major sources of moisture to the Subcontinent, i.e. South Asian Monsoon (SAM), Central Asian westerlies/Western disturbances (WD), and East Asian Monsoon (EAM). These sources do not cover the whole region equally in time and/or space. For example, SAM penetrates the Tethyan and Trans-Himalayan ranges only in case of extreme intensification, and the WD themselves are limited to the northern part of the region. With the current 

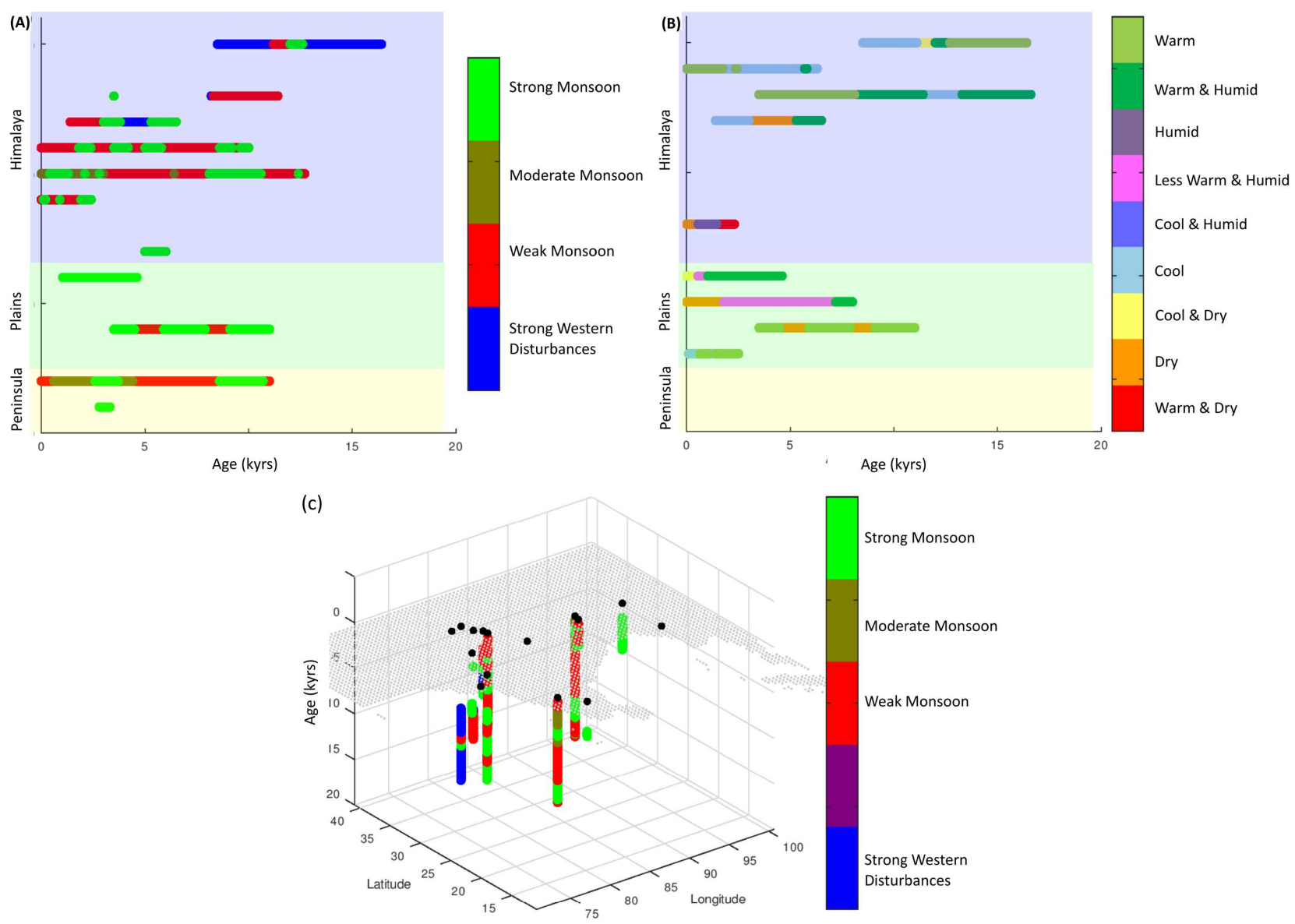

Fig. 2: Comparison of post-LGM records published during 2016-2019. Age-wise distribution of (a) precipitation sources and (b) local climatic conditions. (c) shows the distribution of precipitation sources in space-time

climate change effects, SAM penetration to the north has increased, e.g. study of the Indus water isotopic composition along with two end-member mixing model and the mass balance calculations (Sharma et al., 2017), shows that $\sim 50 \%$ contribution is received from the Mediterranean source (WD) and the SAM contributes the rest. On the other hand, Shafiq et al. (2016) reported that the time series analysis of precipitation recorded at Leh from the year 1901 to 2000 shows that the summer months average precipitation is relatively more $(30.67 \mathrm{~mm})$ as compared to the average winters $(27.38 \mathrm{~mm})$, however the trend is decreasing in summer and increasing in the winter precipitation. Hence, the interpretation of humid and warm climate phases observed via varied proxies anywhere in the subcontinent as South Asian monsoon or Summer monsoon is likely to be erroneous.

\section{The Need for a Palaeo Database}

As seen in Fig. 2, the datasets show some level of expected discrepancy in the variations between different physiographic regions. The records of one region are broadly co-relatable, but then in high time resolutions conflicts emerge. It is difficult to understand whether these are due to differences in local forcing, lead-lag in varied proxies used in interpretation or a combined effect of both. Another point to be noted is that significant gaps in time and space are seen even when including all past reviews of such datasets.

Further, the interpretation varies in different studies and records in their terminology of interpretation. For example, most of the researchers interpret their data in terms of ISM variability. Even the Himalayan records where WD plays a significant role, are interpreted in SAM terms. In other words, a weak monsoon may be understood as a dominant/ 
moderate/weak WD. Terms like SAM/WD mean specific processes in climatology, so using them randomly leads to misinformation. Such questions need to be answered in regional scales for which comparisons are made. Similarly, terms like warm, humid, cold, dry and combination thereof are used often in interpretations. This leads to confusion when comparing different regions, e.g. Himalaya $v_{s}$ Ganga plains, where an interpretation like 'warm \& humid', will have completely different quantifications.

Due to their high temporal resolution and amplification of climate signals, lacustrine records are often used in global climate models (GCM) to test the behaviour of various processes in the past. Inspite of the plethora of climatic data from lakes being generated in India, the GCMs face several problems in their usage. Prime among them is the fact that the very diverse subcontinent has distinct climatic zones which vary spatiotemporally. Further, GCMs cannot use the qualitative interpretations normally found in publications from Indian lakes. Hence, the need of the day is to design the Quaternary Palaeo database leading to a regional palaeoclimatic model to present our data and reconstructions to match those input to GCMs.

\section{The Need for Quantitative Interpretations}

For an accurate prediction of the past and future climate variability, it is very necessary to quantify the proxy data in terms of climatic parameters, e.g. temperature, precipitation etc. The processes which imprint proxies with climate values need to be numerically modelled so that those climatic parameters may be reversely modelled in reconstructions. This will enable us to compare the data locally, regionally and globally to understand the local, regional and global

\section{References}

Ali S N, Dubey J, Ghosh R, Quamar M F, Sharma A, Morthekai P, Dimri A, Shekhar M, Arif M and Agrawal S (2018) High frequency abrupt shifts in the Indian summer monsoon since younger dryas in the Himalaya in Scientific reports 8 9287

Allen S, Ballesteros-Canovas J, Randhawa S, Singha A, Huggel C and Stoffel M (2018) Translating the concept of climate risk into an assessment framework to inform adaptation forcings.

Several sites across the different geomorphicclimatic zones in India should be re-analysed to generate high fidelity records with a stronger chronological framework to strengthen the Holocene climatic reconstructions of the Indian sub-continent following the example in Misra et al. (2018).

\section{Conclusions}

This article discusses the lacustrine record published only since 2016 to present. Improvements are seen in data resolution and chronology via increasing sophistication in instrumental techniques. Time has now come to merge methods so that regional pictures become coherent.

Due to its unique physiogeography, a coherent picture of paleoclimatic variations of the Indian Subcontinent is of importance to Global Climate modelling community. Hence, we must be constant in our endeavours to improve the space-time coverage, error analysis, process interpretations, and time resolutions to provide better palaeo-datasets to the global research community.

\section{Acknowledgements}

This work was performed under the auspices of Birbal Sahni Institute of Palaeosciences, Lucknow, India (BSIP/RDCC/10/19-20). In this review, all the articles published during 2016-19 CE have been considered. If we have missed any, this was inadvertent, and all the researchers who have published their work are duly acknowledged. We are grateful to Prof. D M Banerjee and Prof. Sunil Bajpai, for inviting us to write this review.

planning: Insights from a pilot study of flood risk in Himachal Pradesh, northern India in Environmental science \& policy 87 1-10

Allen S, Fiddes J, Linsbauer A, Randhawa S, Saklani B and Salzmann N (2016a) Permafrost studies in Kullu district, Himachal Pradesh in Current Science 11 257-260

Allen S, Rastner P, Arora M, Huggel C and Stoffel M (2016b) Lake outburst and debris flow disaster at Kedarnath, June 2013: hydrometeorological triggering and topographic 
predisposition in Landslides 13 1479-1491

Allen S K, Linsbauer A, Huggel C, Randhawa S, Schaub Y and Stoffel M (2016c) Current and future glacial lake outburst flood hazard: Application of GIS based modelling in Himachal Pradesh, India In Climate Change, Glacier Response, and Vegetation Dynamics in the Himalaya in (Eds: RB Singh Udo Schickhoff and Suraj Mal) pp 181203 Springer

Allen S K, Linsbauer A, Randhawa S, Huggel C, Rana P and Kumari A (2016d) Glacial lake outburst flood risk in Himachal Pradesh, India: an integrative and anticipatory approach considering current and future threats in Natural Hazards 84 1741-1763

Babeesh C, Lone A and Achyuthan H (2017) Geochemistry of Manasbal lake sediments, Kashmir: weathering, provenance and tectonic setting Journal of the Geological Society of India 89 563-572

Bali R, Chauhan M, Mishra A K, Ali S N, Tomar A, Khan I, Singh D S and Srivastava P (2017) Vegetation and climate change in the temperate-subalpine belt of Himachal Pradesh since 6300 calyrs BP, inferred from pollen evidence of Triloknathpalaeolake in Quaternary International 444 1123

Banerji U S, Bhushan R and Jull A (2019) Signatures of global climatic events and forcing factors for the last two millennia from the active mudflats of Rohisa, southern Saurashtra, Gujarat, western India in Quaternary International $\mathbf{5 0 7}$ 172-187

Basavaiah N, Babu J M, Prizomwala S, Achyuthan H, Siva V and Boral P (2018) Proxy mineral magnetic and elemental analyses for 2004 tsunami impact deposit along the Muttukadu backwater, east coast of India: Scope of the palaeotsunami studies in Quaternary International $\mathbf{5 0 7}$ 224-232

Basu S, Anoop A, Sanyal P and Singh P (2017) Lipid distribution in the lake Ennamangalam, south India: Indicators of organic matter sources and paleoclimatic history in Quaternary International 443 238-247

Basumatary S, Tripathi S, Thakur B, Jalil A and Rahman A(2018a) Mid Holocene vegetation and climatic changes in southwestern Garo hills, Meghalaya, northeast India based on pollen records in Geophytology 48 103-112

Basumatary S K, Nautiyal C M, Ghosh R and Tripathi S (2018b) Modern pollen deposition in wetlands of Majuli island and its implication to decipher palaeoflood episodes in northeast India in Grana 57 273-283

Bhushan R, Sati S, Rana N, Shukla A, Mazumdar A and Juyal N (2018) High-resolution millennial and centennial scale
Holocene monsoon variability in the higher central Himalayas in Palaeogeography Palaeoclimatology Palaeoecology 489 95-104

Blaauw M (2012) Out of tune: the dangers of aligning proxy archives in Quaternary Science Reviews 36 38-49

Blöthe J H, Munack H, Korup O, Fülling A, Garzanti E, Resentini A and Kubik P W (2014) Late quaternary valley infill and dissection in the Indus river, western Tibetan plateau margin in Quaternary Science Reviews 94 102-119

Butcher J B, Nover D, Johnson T E and Clark C M (2015) Sensitivity of lake thermal and mixing dynamics to climate change in Climatic Change 129 295-305

Dar R A, Chandra R, Romshoo S A, Lone M A and Ahmad S M (2015) Isotopic and micromorphological studies of late quaternary loess-paleosol sequences of the Karewa group: Inferences for palaeoclimate of Kashmir valley in Quaternary International 371 122-134

Dee S G, Russell J M, Morrill C, Chen Z and Neary A (2018) Prysm v2 0: A proxy system model for lacustrine archives in Palaeoceanography and Paleoclimatology 33 1250-1269

Farooqui A, Ranjana and Nautiyal C M (2016) Deltaic land subsidence and sea level fluctuations along the east coast of India since $8 \mathrm{ka}$ : A palynological study in The Holocene 26 1426-1437

Ghosh M K, Kumar L and Kibet Langat P (2019a) Geospatial modelling of the inundation levels in the Sundarbans mangrove forests due to the impact of sea level rise and identification of affected species and regions Geomatics in Natural Hazards and Risk 10 1028-1046

Ghosh R, Biswas O, Paruya D K, Agrawal S, Sharma A, Nautiyal C, Bera M and Bera S (2018) Hydroclimatic variability and corresponding vegetation response in the Darjeeling Himalaya, India over the past $\sim 2400$ years in Catena 170 84-99

Ghosh R, Srivastava P, Shukla U, Sehgal R and Singh I (2019b) 100 kyrs sedimentary record of marginal gangetic plain: Implications for forebulge tectonics in Palaeogeography Palaeoclimatology Palaeoecology 520 78-95

Gill E C, Rajagopalan B, Molnar P H, Kushnir Y and Marchitto T M (2017) Reconstruction of Indian summer monsoon winds and precipitation over the past 10,000 years using equatorial pacific SST proxy records in Paleoceanography 32 195-216

Humane, S K, Humane, S S and Chalakh S (2018) Limnological study of Gadchiroli lake, Maharashtra, India using hydrosediment chemistry and sedimentary diatoms in International Journal of Scientific Research in Science and Technology 4 1659-1670 
Jain S K, Agarwal P K and Singh V P (2007) Hydrology and water resources of India, in $\mathbf{5 7}$ Springer Science \& Business Media

Kar R and Quamar M F (2019) Pollen-based quaternary palaeoclimatic studies in India: an overview of recent advances in Palynology 43 76-93

Kathiresan K (2018) Mangrove forests of India in Current Science $114976-981$

Khider D, Ahn S, Lisiecki L, Lawrence C and Kienast M (2017) The role of uncertainty in estimating lead/lag relationships in marine sedimentary archives: a case study from the tropical pacific in Palaeoceanography 32 1275-1290

Kumar O, Devrani R and Ramanathan A (2017) Deciphering the past climate and monsoon variability from lake sediment archives of India: A review in Journal of Climate Change 3 11-23

Lal R, Saini H, Pant N and Mujtaba S (2019) Tectonics induced switching of provenance during the late quaternary aggradation of the Indus river valley, Ladakh, India in Geoscience Frontiers 10 285-297

Linsbauer A, Frey H, Haeberli W, Machguth H, Azam M and Allen S (2016) Modelling glacier-bed overdeepenings and possible future lakes for the glaciers in the HimalayaKarakorum in Annals of Glaciology 57 119-130

Liu Z, Huang S and Jin Z (2018) Breakpoint lead-lag analysis of the last deglacial climate change and atmospheric $\mathrm{CO}_{2}$ concentration on global and hemispheric scales in Quaternary International 490 50-59

Lone A, Babeesh C, Achyuthan H and Chandra R (2017) Evaluation of environmental status and geochemical assessment of sediments, Manasballake, Kashmir, India in Arabian Journal of Geosciences 1092

Lone A M, Achyuthan H, Shah R A and Sangode S J (2018a) Environmental magnetism and heavy metal assemblages in lake bottom sediments, Anchar lake, Srinagar, NW Himalaya, India in International Journal of Environmental Research 12 489-502

Lone A M, Shah R A, Achyuthan H and Fousiya A (2018b) Geochemistry, spatial distribution and environmental risk assessment of the surface sediments: Anchar lake, Kashmir valley, India Environmental earth sciences 7765

Manikandan K, Felix N, Prabu E, Sudhan C and Kannan B (2018) Impacts of heavy metals in the coastal waters of Tamilnadu in Journal of Aquaculture in the Tropics 33 143-154

Meena N K, Prakasam M, Bhushan R, Sarkar S, Diwate P and Banerji U (2017) Last-five-decade heavy metal pollution records from the Rewalsar lake, Himachal Pradesh, India in Environmental Earth Sciences 7639

Menzel P, Anupama K, Basavaiah N, Das B K, Gaye B, Herrmann $\mathrm{N}$ and Prasad S (2015) The use of amino acid analyses in (palaeo-) limnological investigations: A comparative study of four Indian lakes in different climate regimes in Geochimica et Cosmochimica Acta $16025-37$

Mishra P K, Anoop A, Jehangir A, Prasad S, Menzel P, Schettler G, Naumann R, Weise S, Andersen N, Yousuf A, et al. (2014) Limnology and modern sedimentation patterns in high altitude Tso Moriri lake, NW Himalaya-implications for proxy development in Fundamental and Applied Limnology/Archivfür Hydrobiologie 185 329-348

Mishra P K, Anoop A, Schettler G, Prasad S, Jehangir A, Menzel P, Naumann R, Yousuf A, Basavaiah N, Deenadayalan K, et al. (2015a) Reconstructed late quaternary hydrological changes from lake Tso Moriri, NW Himalaya in Quaternary International 371 76-86

Mishra P K, Prasad S, Anoop A, Plessen B, Jehangir A, Gaye B, Menzel P, Weise S M and Yousuf A R (2015b) Carbonate isotopes from high altitude Tso Moririlake (NW Himalayas) provide clues to late glacial and Holocene moisture source and atmospheric circulation changes in Palaeogeography Palaeoclimatology Palaeoecology 425 76-83

Mishra P K, Prasad S, Jehangir A, Anoop A, Yousuf A R and Gaye B (2018a) Investigating the role of meltwater versus precipitation seasonality in abrupt lake-level rise in the high-altitude Tso Moriri lake (India) in Palaeogeography Palaeoclimatology Palaeoecology 493 20-29

Mishra P K, Prasad S, Marwan N, Anoop A, Krishnan R, Gaye B, Basavaiah N, Stebich M, Menzel P and Riedel N (2018b) Contrasting pattern of hydrological changes during the past two millennia from central and northern India: Regional climate difference or anthropogenic impact? In Global and planetary change 161 97-107

Misra P, Tandon S and Sinha R (2018) Holocene climate records from lake sediments in India: Assessment of coherence across climate zones in Earth-Science Reviews 190 370397

Mugilarasan M, Venkatachalapathy R, Sharmila N and Gurumoorthi K (2017) Occurrence of microplastic resin pellets from Chennai and Tinnakkara island: Towards the establishment of background level for plastic pollution in Indian Journal of Geo Marine Sciences 46 1210-1212

Mujtaba S, Lal R, Saini H, Kumar P and Pant N (2018) Formation and breaching of two palaeolakes around Leh, Indus valley, during the late quaternary in Geological Society London Special Publications 462 23-34 
Pant R, Phadtare N, Chamyal L and Juyal N (2005) Quaternary deposits in Ladakh and Karakorum Himalaya: a treasure trove of the palaeoclimate records in Current Science $\mathbf{8 8}$ 1789-1798

Paul D, Kumbhare S V, Mhatre S S, Chowdhury S P, Shetty S A, Marathe N P, Bhute S and Shouche Y S (2016) Exploration of microbial diversity and community structure of Lonarlake: the only hypersaline meteorite crater lake within basalt rock in Frontiers in microbiology 61553

Payo A, Mukhopadhyay A, Hazra S, Ghosh T, Ghosh S, Brown S, Nicholls R J, Bricheno L, Wolf J, Kay S, et al. (2016) Projected changes in area of the Sunderbans mangrove forest in Bangladesh due to SLR by 2100 in Climatic Change 139 279-291

Petrie C A, Singh R N, Bates J, Dixit Y, French C A, Hodell D A, Jones P J, Lancelotti C, Lynam F, Neogi S, et al. (2017) Adaptation to variable environments, resilience to climate change: Investigating land, water and settlement in Indus northwest India in Current Anthropology 58 1-30

Phartiyal B and Sharma A (2009) Soft-sediment deformation structures in the late quaternary sediments of Ladakh: Evidence for multiple phases of seismic tremors in the north western Himalayan region in Journal of Asian Earth Sciences 34 761-770

Phartiyal B, Sharma A and Kothrari G (2013) Damming of river Indus during late quaternary in Ladakh region of transHimalaya, NW India: implications to lake formationclimate and tectonics in Chinese Science Bulletin (Chinese Version) 58(Suppl I) 142-155

Phartiyal B, Sharma A, Srivastava P and Ray Y (2009) Chronology of relict lake deposits in the Spitiriver, NW trans Himalaya: Implications to late Pleistocene-Holocene climate-tectonic perturbations in Geomorphology 108 264-272

Phartiyal B, Sharma A, Upadhyay R, Sinha A K, et al. (2005) Quaternary geology, tectonics and distribution of palaeoand present fluvio/glacio lacustrine deposits in Ladakh, NW Indian Himalaya - a study based on field observations in Geomorphology 65 241-256

Prasad S, Mishra P K, Menzel P, Gaye B, Jehangir A and Yousuf A R (2016) Testing the validity of productivity proxy indicators in high altitude Tso Moriri lake, NW Himalaya (India) in Palaeogeography Palaeoclimatology Palaeoecology 449 421-430

Prizomwala S, Gandhi D, Bhatt N, Winkler W, Kumar M R, Makwana N and Bhatt N (2018) Geological evidence for AD 1008 tsunami along the Kachchh coast, western India: Implications for hazard along the Makran subduction zone in Scientific Reports 816816
Raj R, Chamyal L, Prasad V, Sharma A, Tripathi J K and Verma P (2015) Holocene climatic fluctuations in the Gujarat alluvial plains based on a multiproxy study of the Pariyaj lake archive, western India in Palaeogeography Palaeoclimatology Palaeoecology 421 60-74

Raja P, Achyuthan H, Farooqui A, Ramesh R, Kumar P and Chopra S (2019) Tropical rainforest dynamics and palaeoclimate implications since the late Pleistocene, Nilgiris, India in Quaternary Research 91 367-382

Raja P, Achyuthan H, Geethanjali K, Kumar P and Chopra S (2018) Late Pleistocene palaeoflood deposits identified by grain size signatures, Parson's valley lake, Nilgiris, Tamilnadu in Journal of the Geological Society of India 91 547-553

Ranhotra P S, Sharma J, Bhattacharyya A, Basavaiah N and Dutta K (2018) Late Pleistocene-Holocene vegetation and climate from the palaeolake sediments, Rukti valley, Kinnaur, Himachal Himalaya in Quaternary International $47979-89$

Ray D, Upadhyay D, Misra S, Newsom H E and Ghosh S (2017) New insights on petrography and geochemistry of impactites from the Lonar crater, India in Meteoritics \& Planetary Science 52 1577-1599

Ruiz-Villanueva V, Allen S, Arora M, Goel N K and Stoffel M (2017) Recent catastrophic landslide lake outburst floods in the Himalayan mountain range Progress in Physical Geography 41 3-28

Sajinkumar K, Revathy A and Rani V (2017) Hydrogeochemistry and spatiotemporal changes of a tropical coastal wetland system: Veliakkulam lake, Thiruvananthapuram, India in Applied Water Science 7 1521-1534

Sandeep K, Shankar R, Warrier A K, Yadava M, Ramesh R, Jani R, Weijian Z and Xuefeng L (2017) A multi-proxy lake sediment record of Indian summer monsoon variability during the Holocene in southern India in Palaeogeography Palaeoclimatology Palaeoecology 476 1-14

Sangode S, Rawat S, Meshram D, Phadtare N and Suresh N (2013) Integrated mineral magnetic and lithologic studies to delineate dynamic modes of depositional conditions in the Leh valley basin, Ladakh Himalaya, India in Journal of the Geological Society of India 82 107-120

Santhanam H, Farooqui A and Karthikeyan A (2018) Bloom of the diatom, biddulphia sp and ecology of Pulicat lagoon, southeast India in the aftermath of the 2015 north east monsoonal rainfall in Environmental monitoring and assessment 190636

Sanwal J, Rajendran C and Sheshshayee M (2019) Reconstruction of late quaternary climate from a paleo-lacustrine profile 
in the central (Kumaun) Himalaya: Viewing the results in a regional context in Frontiers in Earth Science 72

Sarkar S, Prakasam M, Upasana S, Bhushan R, Gaury P K and Meena N K (2016) Rapid sedimentation history of Rewalsar lake, lesser Himalaya, India during the last fifty years-estimated using $\mathrm{Cs}$ and $\mathrm{Pb}$ dating techniques: a comparative study with other north-western Himalayan lakes in Himalayan Geology 37 1-7

Saxena A and Singh D S (2017) Multiproxy records of vegetation and monsoon variability from the lacustrine sediments of eastern Ganga plain since 1350 ad Quaternary International 444 24-34

Saxena A and Trivedi A (2017) Pollen based vegetation and climate change records deduced from the lacustrine sediments of Kikartal (lake), central Ganga plain, India in Palaeobotanist 66 37-46

Shafiq M, Bhat M, Rasool R, Ahmed P, Singh H and Hassan H (2016) Variability of precipitation regime in Ladakh region of India from 1901-2000 in Journal of Climatology \& Weather Forecasting 42

Shah R A, Achyuthan H, Lone A M and Ramanibai R (2017) Diatoms, spatial distribution and physicochemical characteristics of the Wular lake sediments, Kashmir valley, Jammu and Kashmir in Journal of the Geological Society of India 90 159-168

Sharma A, Kumar K, Laskar A, Singh S K and Mehta P (2017) Oxygen, deuterium, and strontium isotope characteristics of the Indus river water system in Geomorphology 284 516

Sharma T K, Mawlankar R, Sonalkar V V, Shinde V K, Zhan J, Li W-J, Rele M V, Dastager S G and Kumar L S (2016) Streptomyces lonarensisspnov, isolated from Lonarlake, a meteorite salt water lake in India in Antonie van Leeuwenhoek 109 225-235

Sivaram K, Gupta S, Kumar S and Prasad B (2018) Shear velocity structural characterization around the Lonar crater using joint inversion of ambient noise HVSR and Rayleigh wave dispersion in Journal of Applied Geophysics 159 773-784

Smerdon J E and PAGES 2k-PMIP3 group (2015) Continentalscale temperature variability in PMIP3 simulations and pages $2 \mathrm{k}$ regional temperature reconstructions over the past millennium in Climate of the Past 11 1673-1699

Sreekumari V M, John S E, Rajan R T, Kesavan M, Kurian S and Damodaran P (2016) Human interventions and consequent environmental degradation of a protected freshwater lake in Kerala, SW India in Geosciences Journal 20 391-402
Srivastava J and Farooqui A (2017a) Fluctuations in relative sea level and mangroves in the Coleroon estuary since $\sim 46 \mathrm{ka}$ : A palynological study from SE coast of India in Geophytology 47 11-26

Srivastava J and Farooqui A(2017b) Holocene climate and relative sea level changes in Cauvery river delta, India based on pollen and sedimentary records in Journal of the Palaeontological Society of India 62 193-204

Srivastava J, Farooqui A and Seth P (2018) Pollen-vegetation relationship in surface sediments, Coringa mangrove ecosystem, India: Palaeoecological applications in Palynology 43 451-466

Srivastava P, Agnihotri R, Sharma D, Meena N, Sundriyal Y, Saxena A, Bhushan R, Sawlani R, Banerji U S, Sharma C, et al. (2017) 8000-year monsoonal record from Himalaya revealing reinforcement of tropical and global climate systems since mid-Holocene in Scientific Reports 714515

Tripathi S, Singh Y R, Nautiyal C M and Thakur B (2018) Vegetation history, monsoonal fluctuations and anthropogenic impact during the last 2330 years from Loktaklake (Ramsar site), Manipur, north-east India: a pollen-based study in Palynology 42 406-419

Trivedi A, Saxena A, Chauhan M, Sharma A, Farooqui A, Nautiyal C, Yao YF, Wang Y-F, Li C-S and Tiwari D (2019) Vegetation, climate and culture in central Ganga plain, India: A multi-proxy record for last glacial maximum in Quaternary International 507 134-147

Valdiya K (1988) Tectonics and evolution of the central sector of the Himalaya in Philosophical Transactions of the Royal Society of London; Series A Mathematical and Physical Sciences 326 151-175

Valdiya K (2001) Reactivation of terrane-defining boundary thrusts in central sector of the Himalaya: implications in Current Science 81 1418-1431

Van Oldenborgh G J (2018) Extreme heat in India and anthropogenic climate change in Natural Hazards and Earth System Sciences 18 365-381

Veerasingam S, Mugilarasan M, Venkatachalapathy R and Vethamony P (2016) Influence of 2015 flood on the distribution and occurrence of microplastic pellets along the Chennai coast in India Marine pollution bulletin 109 196-204

Vijayaraj R and Achyuthan H (2016) Organic matter source in the freshwater tropical lakes of southern India in Current Science 111 168-176. 